\title{
Effects of bioaugmentation by an anaerobic lipolytic bacterium on anaerobic digestion of lipid-rich waste
}

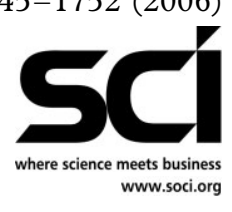

\author{
Dores G. Cirne, ${ }^{1,2 *}$ Lovisa Björnsson, ${ }^{1}$ Madalena Alves ${ }^{2}$ and Bo Mattiasson ${ }^{1}$ \\ ${ }^{1}$ Department of Biotechnology, Center for Chemistry and Chemical Engineering, Lund University, Lund, Sweden \\ ${ }^{2}$ Centro de Engenharia Biologica, Universidade do Minho, PT-4710-057 Braga, Portugal
}

\begin{abstract}
The effect of bioaugmentation with an anaerobic lipolytic bacterial strain on the anaerobic digestion of restaurant lipid-rich waste was studied in batch experiments with a model waste containing $10 \%$ lipids (triolein) under two sets of experimental conditions: (A) methanogenic conditions, and (B) initially acidogenic conditions in the presence of only the lipolytic strain biomass (4 days), followed by methanogenic conditions. The bioaugmenting lipolytic strain, Clostridium lundense (DSM 17049 ${ }^{\mathrm{T}}$ ), was isolated from bovine rumen. The highest lipolytic activity was detected at the beginning of the experiments. A higher methane production rate, $27.7 \mathrm{~cm}^{3} \mathrm{CH}_{4(\mathrm{STP})} \mathrm{g}^{-1} \mathrm{VS}_{\text {added }} \mathrm{day}^{-1}$ (VS, volatile solids) was observed in experiment A with the presence of the bioaugmenting lipolytic strain under methanogenic conditions. The highest initial oleate concentration, $99 \%$ of the total oleate contained in the substrate, was observed in the experiments with the bioaugmenting lipolytic strain under treatment A conditions; the levels of palmitate and stearate were also higher until day 15, indicating that the bioaugmentation strategy improved the hydrolysis of the lipid fraction. In general, the results indicated that degradation of the long chain fatty acids (LCFAs) controlled the digestion process.

(C) 2006 Society of Chemical Industry
\end{abstract}

Keywords: biological anaerobic treatment; bioaugmentation; inhibition; hydrolysis; lipid-rich waste; LCFA

\section{INTRODUCTION}

Lipids (characterized as oil, grease, fat and free long chain fatty acids, LCFAs) can be a major organic component in wastewater. Approximately 15-20\% of the total solids in sewage sludge consists of lipids. ${ }^{1}$ Lipids are preferentially found as triglycerides, and oleate is one of the most abundant LCFAs. ${ }^{2,3}$ Triglycerides can comprise up to $65 \%(\mathrm{w} / \mathrm{w})$ of meat industry waste and contribute to waste solids from the food processing industry. ${ }^{4}$ Large amounts of lipid-rich waste are also generated in the edible oil processing industry, in the dairy industry and in restaurant waste. Lipids are attractive substrates for anaerobic digestion due to the higher methane yield obtained compared with proteins or carbohydrates. ${ }^{5}$ However, anaerobic microbial degradation of lipids is one of the least investigated topics in this area.

There is much discussion in the literature as to which step limits conversion of the substrate to biogas when complex substrates such as lipids are degraded. Studies have shown that the hydrolysis of lipids to glycerol and LCFAs can be rapid, and that the main problem during lipid digestion is the further degradation of LCFAs. ${ }^{6,7}$ However, the substrate interface area available for hydrolysis may be a limiting factor. ${ }^{8}$ In the case of slaughterhouse wastewater, where high amounts of suspended solids are present, the liquefaction of colloids adsorbed onto the biomass and the hydrolysis of suspended solids entrapped within the biomass bed were found to be the limiting steps in biodegradation. ${ }^{9}$ Petruy and Lettinga ${ }^{10}$ also found liquefaction to be the rate limiting step during the digestion of milk fat. Salminen and co-workers ${ }^{11}$ reported that hydrolysis limited the digestion of a poultry slaughterhouse waste due to a high concentration of propionate, which was the consequence of the presence of LCFAs. The type of lipid also has an influence on what step in the degradation process will be limiting. ${ }^{12}$ Lipid hydrolysis limitation has not been studied as much as LCFAs degradation. Different pretreatment methods have been investigated to improve the digestion process, such as: (1) chemical pretreatment of the waste by $\mathrm{NaOH}, \mathrm{Ca}(\mathrm{OH})_{2}$ or $\mathrm{HCl}$; (2) enzyme addition; and (3) biological pretreatment by utilization of hydrolytic microorganisms, covering a variety of wastes, such as activated sludge, lipid-rich wastewaters, household solid waste and slaughterhouse wastewater. ${ }^{2,6}$ Each method, however, has serious drawbacks. Masse and co-workers ${ }^{6}$ do not recommend pretreatment with an alkali because it results in an increase in $\mathrm{pH}$ in the digestion process. Pretreatment by enzyme addition was shown to have positive effects (increased free LCFAs concentration), however, the process can be expensive and thus not economically feasible. The possibility of pretreatment with enzyme-producing aerobic

* Correspondence to: Dores G. Cirne, Department of Biotechnology, Center for Chemistry and Chemical Engineering, Lund University, P.O. Box 124, SE-221 00, Lund, Sweden 
microorganisms has been demonstrated with a lipolytic fungus ${ }^{13}$ and with mixed bacterial cultures comprising lipase, protease and amylase producers. ${ }^{14}$ However, when using aerobic microorganisms for pretreatment, oxygen supply may be required, increasing the cost of the process. While the addition of anaerobic microorganisms has been investigated as a means of improving xylanolytic, cellulolytic and hemicellulolytic activities, it has, to the authors' knowledge, not previously been investigated using strains exhibiting lipolytic activity. ${ }^{15,16}$

In the present study, the effect of bioaugmentation by an anaerobic lipolytic strain as a means of improving hydrolysis and solubilization of lipids in the anaerobic digestion process of restaurant lipid-rich waste was studied using a model substrate. The bioaugmenting lipolytic bacterium is a strict anaerobe isolated from bovine rumen. ${ }^{17}$

\section{MATERIALS AND METHODS \\ Substrate}

The effect of bioaugmentation on the anaerobic digestion of lipid-rich waste was studied in batch experiments using a well-defined substrate (Table 1). The substrate composition was based on the composition of the restaurant waste from the University of Minho, located in Campus de Gualtar (Braga, Portugal). This waste consisted of a one week basis sample from the waste produced in the restaurant. The amount of each component was based on the chemical oxygen demand (COD); $10 \%$ was the contribution from lipids, $45 \%$ from protein, and $45 \%$ from carbohydrate $(30 \%$ from starch and $15 \%$ from cellulose) (Table 1). Nutrients with the following final composition were added to ensure that no nutrient deficiency would occur $\left(\mathrm{mg} \mathrm{dm}{ }^{-3}\right):^{18} \mathrm{NH}_{4} \mathrm{Cl}, 1000 ; \mathrm{NaCl}, 100 ; \mathrm{MgCl}_{2}$. $6 \mathrm{H}_{2} \mathrm{O}, 100 ; \mathrm{CaCl}_{2} \cdot 2 \mathrm{H}_{2} \mathrm{O}, 50 ; \mathrm{K}_{2} \mathrm{HPO}_{4} \cdot 3 \mathrm{H}_{2} \mathrm{O}$, 400; cysteine $\mathrm{HCl}, 500 ; \mathrm{FeCl}_{2} \cdot 2 \mathrm{H}_{2} \mathrm{O}, 2 ; \mathrm{H}_{3} \mathrm{BO}_{3}$, $0.050 ; \mathrm{ZnCl}_{2}$ 0.050; $\mathrm{CuCl}_{2}, 0.030 ; \mathrm{MnCl}_{2} \cdot 4 \mathrm{H}_{2} \mathrm{O}$, 0.050; $\left(\mathrm{NH}_{4}\right)_{6} \mathrm{Mo}_{7} \mathrm{O}_{24} \cdot 4 \mathrm{H}_{2} \mathrm{O}, 0.050 ; \mathrm{AlCl}_{3}, 0.050$; $\mathrm{CoCl}_{2} \cdot 6 \mathrm{H}_{2} \mathrm{O}, 0.050 ; \mathrm{NiCl}_{2}, 0.050$; EDTA, 0.500; $\mathrm{Na}_{2} \mathrm{SeO}_{3} \cdot 5 \mathrm{H}_{2} \mathrm{O}, 0.100$; biotin, 0.020 ; folic acid, 0.020 ; pyridoxine $\mathrm{HCl}, 0.100$; riboflavin, 0.005 ; thiamine $\mathrm{HCl}, 0.005$; cyanocobalamine, 0.001 ; nicotinic

Table 1. Composition of the substrate used in the experiments

\begin{tabular}{lcccc}
\hline & \multicolumn{3}{c}{ Composition } & \\
\cline { 2 - 4 } & $\begin{array}{c}\mathrm{COD} \\
\left(\mathrm{g} \mathrm{g}^{-1}\right)\end{array}$ & $\begin{array}{c}\mathrm{TS} \\
\left(\mathrm{g} \mathrm{g}^{-1}\right)\end{array}$ & $\begin{array}{c}\mathrm{TKN}^{\mathrm{a}} \\
\left(\mathrm{g} \mathrm{g}^{-1}\right)\end{array}$ & $\begin{array}{c}\text { Amount } \\
(\mathrm{COD} \%)\end{array}$ \\
Substrate & 2.67 & 1.01 & 0 & 10 \\
\hline $\begin{array}{c}\text { Lipid - triolein (65\% } \\
\text { purity) }\end{array}$ & 1.25 & 0.94 & 0.12 & 45 \\
$\begin{array}{c}\text { Protein - whey protein } \\
\quad \text { (80\% purity) }\end{array}$ & 1.01 & 0.92 & 0 & 30 \\
$\begin{array}{c}\text { Carbohydrate - soluble } \\
\text { starch }\end{array}$ & 1.10 & 0.96 & 0 & 15 \\
$\begin{array}{c}\text { Carbohydrate - } \alpha \text { - } \\
\text { cellulose }\end{array}$ & & & & \\
\hline
\end{tabular}

a TKN - Total Kjeldahl nitrogen. acid, 0.005; p-aminobenzoic acid, 0.005; lipoic acid, 0.005; and DL-panthothenic acid, 0.005. The $\mathrm{pH}$ was adjusted to 7.0 with $5 \mathrm{moldm}^{-3} \mathrm{NaOH}$. Bicarbonate was added at a concentration of $14 \mathrm{~g} \mathrm{dm}^{-3}$ to provide buffering capacity. The final substrate total solids (TS) content in the experiments was $6.2 \%$ and the total COD was $0.8 \mathrm{~g}$ per bottle, corresponding to $33.3 \mathrm{~g} \mathrm{dm}^{-3}$.

\section{Methanogenic inoculum}

Sludge from an anaerobic digester treating municipal sewage sludge and potato processing waste (TS $4.8 \%$ and volatile solids, VS 3.1\%) (Ellinge, Sweden) was used as inoculum at a VS ratio of 1.35 (substrate:inoculum).

\section{Bioaugmenting strain}

The bioaugmenting lipolytic strain (Clostridium lundense, DSM $17049^{\mathrm{T}}$ ) was isolated from bovine rumen fluid. ${ }^{17}$ The cells were cultivated for $88 \mathrm{~h}$ in an anaerobic medium consisting of the basal salts described by Markossian and co-workers, ${ }^{19} 0.0025 \%$ (w/v) rezasurin, $120 \mathrm{mg} \mathrm{dm}^{-3}$ L-cysteine hydrochloride, peptone, yeast extract and glucose all at $0.5 \%(\mathrm{w} / \mathrm{v})$; olive oil $2 \%(\mathrm{v} / \mathrm{v})$ was the lipid source. The culture broth was washed once with oxygen-free distilled water to remove most of the remaining substrate. The amount of lipolytic strain biomass added corresponded to $1.3 \%$ of the VS of the methanogenic inoculum added.

\section{Experimental set-up}

The effect of bioaugmentation on the overall biomethanation process was studied under two kinds of conditions: treatment (A), methanogenic conditions where the lipolytic strain biomass was added on day 0 together with the methanogenic inoculum; and treatment (B), initially acidogenic conditions followed by methanogenic conditions. In this case, only the lipolytic strain biomass was added at day 0 , and after 4 days the methanogenic inoculum was added. Control experiments without substrate were used to evaluate the contribution of the methanogenic inoculum alone (blank 1) as well as together with active (blank 2) and inactivated lipolytic strain biomass (autoclaved for $40 \mathrm{~min}$ at $121^{\circ} \mathrm{C}$ ) (blank 3). Control experiments were also performed with substrate and methanogenic inoculum in the presence (control 1) and absence of inactivated lipolytic strain biomass (control 2). The tests were performed in $100 \mathrm{~cm}^{3}$ serum bottles with a liquid volume of $24 \mathrm{~cm}^{3}$ kept in a nitrogen atmosphere. The bottles were incubated at $37^{\circ} \mathrm{C}$ with agitation (stirring) at $150 \mathrm{rpm}$. Assays were run using 11 replicates and at liquid phase sampling, one vial was randomly taken for analysis. ${ }^{1,11}$ Three bottles were used for gas phase studies during the experiment and the liquid contents in these were analysed at the end of the experiment. Liquid phase sampling was performed on days $0,1,2,3,5,9,15,22$ and on the final day in treatment $\mathrm{A}$ and on days $0,1,2,4$ (before and after 
the addition of the methanogenic inoculum), 5, 9, 12 and on the final day in treatment $B$.

\section{Analysis}

Biogas production was measured using a handheld pressure transducer capable of measuring a pressure variation of 2 bar $(0$ to $\pm 202.6 \mathrm{kPa})$ over a device range of -200 to $+200 \mathrm{mV}$, with a minimum detectable variation of 0.005 bar, corresponding to $0.05 \mathrm{~cm}^{3}$ of biogas in a $10 \mathrm{~cm}^{3}$ headspace (Centrepoint Electronics, Galway, Ireland). ${ }^{20}$ Gas composition was analysed using a Varian 3350 GC-TCD (Walnut Creek, CA, USA) in accordance with the method of Mshandete et al. ${ }^{21}$ The values of methane production were corrected for standard temperature and pressure conditions (STP). For liquid phase sample analysis, the whole content of a serum bottle was centrifuged at $4000 \mathrm{rpm}$ for $30 \mathrm{~min}$. The supernatant was taken for analysis of concentration of volatile fatty acids (VFAs), lipase activity and soluble COD. The solids were washed twice with $10 \mathrm{~cm}^{3}$ of distilled water, acidified with $5 \mathrm{moldm}^{-3}$ of $\mathrm{HCl}$ to $\mathrm{pH} \mathrm{2,} \mathrm{and}$ stored at $-20^{\circ} \mathrm{C}$ for analysis of biomass-associated LCFAs. Aliquots of the biomass (ranging from 2 to $4 \mathrm{~cm}^{3}$ ) were dried at $105^{\circ} \mathrm{C}$ for $20 \mathrm{~h}$. The total lipids were extracted from the dried solids as described by Bligh and Dyer. ${ }^{22}$ Samples $\left(1.5 \mathrm{~cm}^{3}\right)$ from the chloroform extract were passed through silica-based columns (Bond Elut ${ }^{\circledR}$ LRC-Si, $100 \mathrm{mg}$, Varian, Middelburg, the Netherlands) for separation of the different classes of lipids. The neutral lipid fraction was eluted with $1.5 \mathrm{~cm}^{3}$ chloroform and the eluate was evaporated under nitrogen. The LCFAs present in the residue were then methylated by dissolving them in a methylation agent (methanol containing $5 \%(\mathrm{v} / \mathrm{v})$ sulphuric acid). The reaction was allowed to proceed for $2 \mathrm{~h}$ at $50^{\circ} \mathrm{C}$, and was stopped by adding $5 \mathrm{~cm}^{3}$ of a $5 \%(\mathrm{w} / \mathrm{v}) \mathrm{NaCl}$ solution. Finally, the methyl esters were extracted twice with $5 \mathrm{~cm}^{3}$ n-hexane. ${ }^{23}$ The extracts were stored at $-20^{\circ} \mathrm{C}$ until analysis. LCFA methyl esters were analysed using a Varian 3400 GC-FID as described by Lyberg et al. ${ }^{24}$

Total solids, VS and COD (total and soluble) were measured according to standard methods. ${ }^{25}$ The COD of the substrate components was determined using suspensions of each component, which were homogenized using a homogenizer Disp 25 (20 500 rpm; Inter Med, Roskilde Denmark). Volatile fatty acid concentrations were measured using HPLC in accordance with the method of Mshandete et al. ${ }^{21}$ Lipase activity was measured in accordance with the method of Winkler and Stuckmann (1979). ${ }^{26}$ The assay, using $p$-nitrophenylpalmitate $\left(0.30 \mathrm{~g} \mathrm{dm}^{-3}\right)$ (Sigma St Louis, MO, USA) as substrate in Sörensen phosphate buffer ( $\mathrm{pH} 8.0,0.05 \mathrm{~mol} \mathrm{dm}^{-3}$ ) containing isopropanol $\left(10 \mathrm{~cm}^{3}\right.$ per $90 \mathrm{~cm}^{-3}$ of buffer), sodium deoxycholate $\left(2.07 \mathrm{~g} \mathrm{dm}^{-3}\right)$ and gum arabic $\left(1.00 \mathrm{~g} \mathrm{dm}^{-3}\right)$, was carried out with incubation at $37^{\circ} \mathrm{C}$ for $15 \mathrm{~min}$ followed by measuring the absorbance at $410 \mathrm{~nm}$ against a control with inactivated enzyme. One enzyme IU is defined as $1 \mu \mathrm{mol}$ of $p$-nitrophenol enzymatically released from the substrate per minute under the conditions of the assay. Total Kjeldahl nitrogen was determined after digestion of samples according to the manufacturer's instructions by colorimetric analysis using a FIAStar 5000 analyser coupled to a 5027 sampler (Foss Tecator AB Höganäs, Sweden). The pH was measured with a CG $842 \mathrm{pH}$ meter (Schoot, Geräte $\mathrm{GmbH}$, Hofheim, Germany) immediately after sampling.

\section{RESULTS}

\section{Methane production}

A higher methane production rate was observed in the presence of the bioaugmenting lipolytic strain biomass in treatment A (Fig. 1 and Table 2). In treatment $\mathrm{B}$, no bioaugmentation effects were observed. For all conditions investigated, the percentage of substrate methanization was above $90 \%$, i.e. the fraction of the theoretical methane yield that was obtained experimentally (Table 2). The methane yields obtained were similar for test samples and controls for both treatments (Table 2).

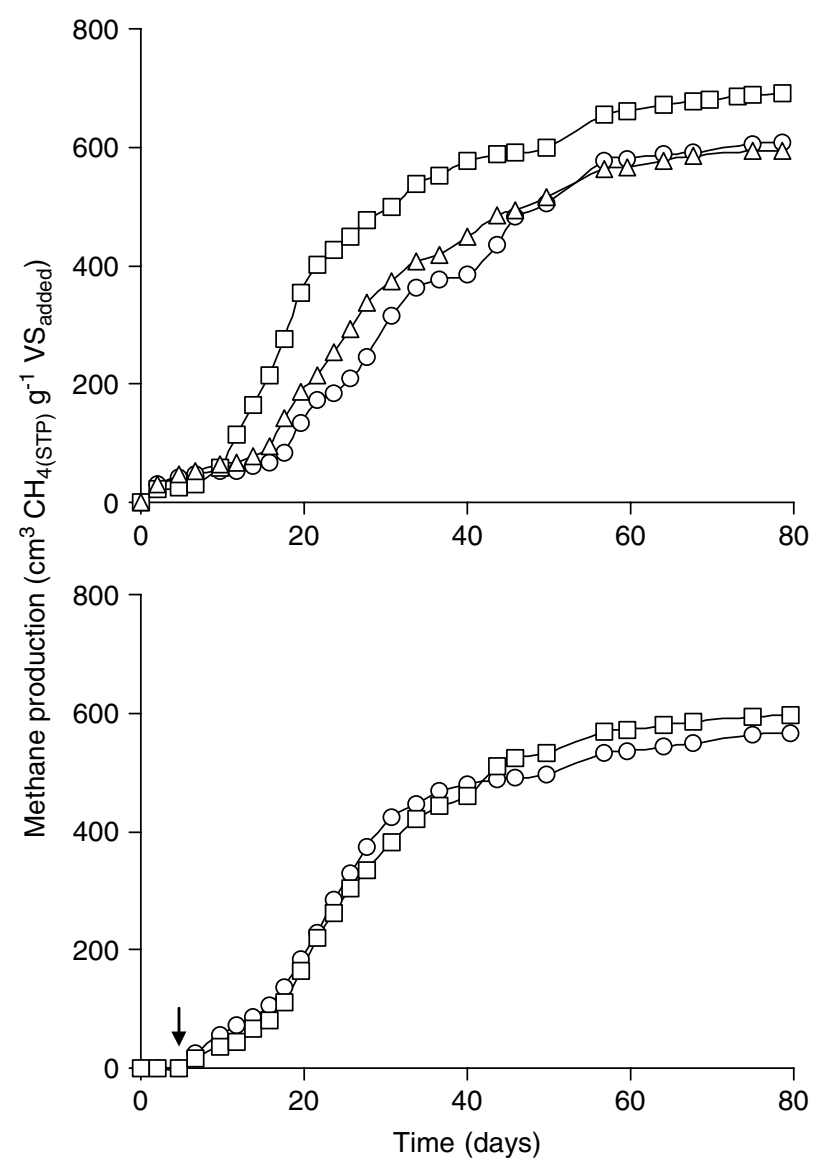

Figure 1. Specific cumulative methane production; top - treatment $A$, bottom - treatment $B$. The arrow indicates the addition of methanogenic inoculum in treatment $B$; inocula methane production not subtracted. -O- control $1 ;-\triangle$ - control $2 ;-\square$ - test sample. 

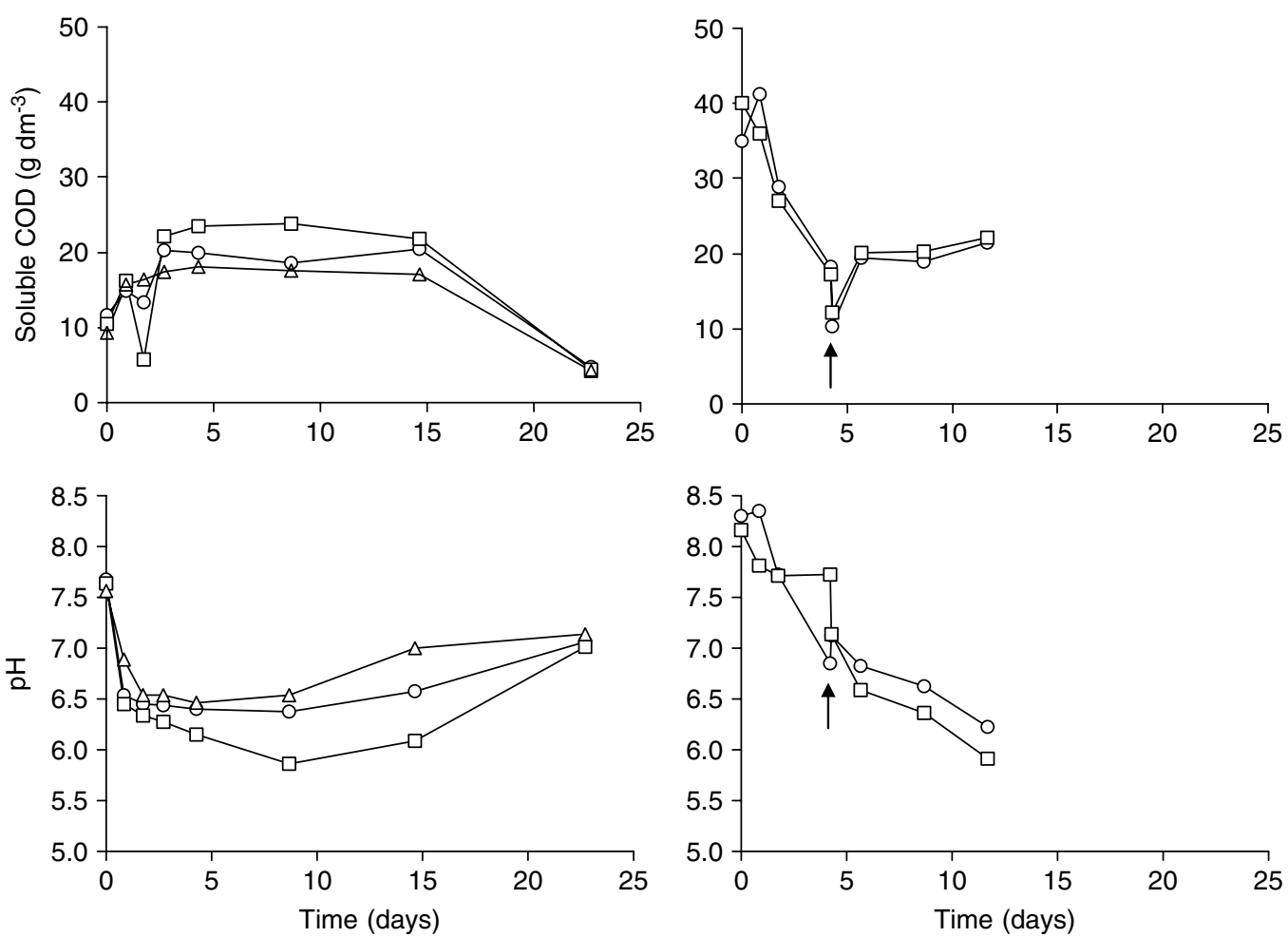

Figure 2. Soluble COD (top) and $\mathrm{pH}$ (bottom) profiles up to day 22; left - treatment $\mathrm{A}$, right - treatment $\mathrm{B}$. The arrow indicates the addition of methanogenic inoculum in treatment B. -O- control 1; - $\triangle$ - control 2; - $\square$ - test sample.

Table 2. Summary of the results of biomethanation experiments (mean values \pm standard deviation are shown, $n=3$ )

\begin{tabular}{|c|c|c|c|c|c|}
\hline \multirow[b]{2}{*}{ Parameter } & \multicolumn{3}{|c|}{ Treatment A } & \multicolumn{2}{|c|}{ Treatment B } \\
\hline & Control 1 & Control 2 & Test sample & Control 1 & Test sample \\
\hline $\begin{array}{l}\text { Maximum methane production rate }\left(\mathrm{cm}^{3} \mathrm{CH}_{4(\mathrm{STP})} \mathrm{g}^{-1}\right. \\
\left.\mathrm{VS}_{\text {added }} \text { day }^{-1}\right)\end{array}$ & $21.6 \pm 1.5^{\mathrm{C}}$ & $18.7 \pm 1.1^{d}$ & $27.7 \pm 1.0^{\mathrm{e}}$ & $24.0 \pm 3.5^{f}$ & $25.2 \pm 3.5^{9}$ \\
\hline $\begin{array}{l}\text { Methane yield }{ }^{\mathrm{a}}\left(\mathrm{cm}^{3} \mathrm{CH}_{4(\mathrm{STP})} \mathrm{g}^{-1} \mathrm{VS}_{\text {added }}\right) \\
\text { Percentage methanization } \\
\mathrm{b}(\%)\end{array}$ & $\begin{array}{c}447 \pm 36 \\
98 \pm 8\end{array}$ & $\begin{array}{c}434 \pm 103 \\
95 \pm 23\end{array}$ & $\begin{array}{c}444 \pm 26 \\
98 \pm 6\end{array}$ & $\begin{aligned} 415 & \pm 5 \\
91 & \pm 1\end{aligned}$ & $\begin{array}{c}444 \pm 41 \\
98 \pm 9\end{array}$ \\
\hline
\end{tabular}

a Inocula, i.e. methanogenic biomass and lipolytic strain biomass methane production subtracted.

${ }^{b}$ Calculated by comparison with the theoretical methane potential of the substrate after subtracting inocula's methane production.

${ }^{c}$ Determined between days 18 and 22.

${ }^{d}$ Determined between days 16 and 26 .

e Determined between days 10 and 26.

${ }^{f}$ Determined between days 18 and 28

9 Determined between days 18 and 24 .

\section{COD and $\mathrm{pH}$}

The initial soluble COD was similar for test samples and controls (Fig. 2). In treatment A the soluble COD observed was slightly higher when the active lipolytic strain biomass was present. For both the test sample and control 1 (containing inactivated lipolytic strain biomass), higher concentrations of soluble COD were observed than in control 2 (with only methanogenic inoculum) with the exception of a deviation on day 2 . After day 15, the soluble COD decreased for the test sample and controls under treatment A conditions. In treatment $\mathrm{B}$, no differences between the test sample and control with inactivated lipolytic strain biomass were observed. On day 4 the soluble COD decreased due to a dilution effect caused by the addition of the methanogenic inoculum. Thereafter, as a consequence of microbial activity, the soluble COD concentration increased. In treatment $\mathrm{A}$ the $\mathrm{pH}$ showed substantial differences between test sample and controls, with the $\mathrm{pH}$ always lower in the test sample than in controls.

\section{Biomass-associated LCFAs and lipolytic activity}

The biomass-associated LCFAs were analysed only in treatment A since adding the lipolytic strain biomass produced significant effects. Higher initial oleate concentration was detected in the experiment in which the active lipolytic strain was added, corresponding to $99 \%$ of the total oleate that could be released by trioleate hydrolysis (Fig. 3). This observation was in agreement with the lipolytic activity data (data not shown). The initial lipolytic 

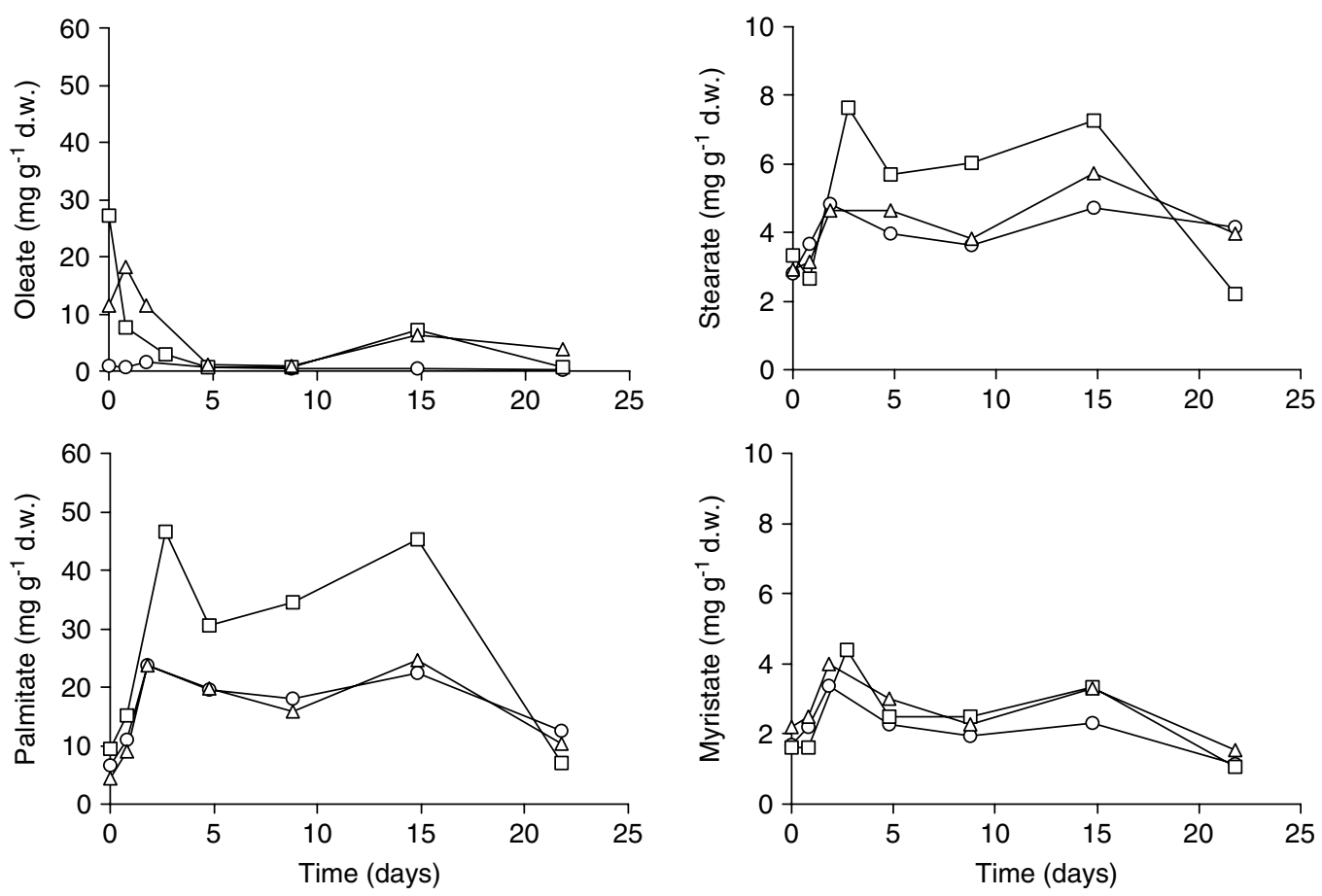

Figure 3. LCFA profiles up to day 22 in treatment A. -O- control 1; - $\triangle$ - control 2; - $\square$ - test sample.

activity $\left(91 \mathrm{IU} \mathrm{dm}^{-3}\right.$ ) was approximately 2.5 times higher than in the controls. The highest activity was observed at the beginning of the experiment. After $24 \mathrm{~h}$ of incubation the measurable lipolytic activity decreased to $5 \mathrm{IU} \mathrm{dm}^{-3}$. In treatment $\mathrm{B}$, after $24 \mathrm{~h}$, the lipolytic activity decreased to $57 \%$ of the initial value. After the initial high concentration, the oleate concentration decreased to low values, while stearate and palmitate concentrations increased to values above 7.5 and $40 \mathrm{mg} \mathrm{g}^{-1}$ d.w. (d.w., dry weight), respectively (Fig. 3). The palmitate concentration in the test sample remained higher than in the controls until day 15 , after which it decreased to $7 \mathrm{mgg}^{-1}$ d.w. The stearate concentration was also higher in the test sample until day 15 (6-8 $\mathrm{mg} \mathrm{g}^{-1}$ d.w.). No significant differences were observed between the test sample and controls for myristate and the concentrations were the lowest observed, $2-4 \mathrm{mg} \mathrm{g}^{-1}$ d.w.

\section{VFAs}

Acetate $\left(6-8 \mathrm{~g} \mathrm{dm}^{-3}\right)$ and propionate $\left(2.5-4 \mathrm{~g} \mathrm{dm}^{-3}\right)$ were the most abundant acids for both treatment conditions investigated (Fig. 4). The concentration of acetate was higher in the test sample for treatment A. After day 15, the concentration of acetate decreased while a slight increase in propionate concentration was observed. Other VFAs showed similar levels in test sample and controls for both treatment conditions investigated (Fig. 4). In treatment $\mathrm{B}$, data obtained after the addition of the methanogenic inoculum (day 4) and up to day 12 are presented. The initial hydrolysis of the lipid fraction of the substrate had no significant effect on the VFAs produced (data not shown). At the end of the experiments, the concentration of VFAs was between $0.2 \mathrm{~g} \mathrm{dm}^{-3}$ and $1 \mathrm{~g} \mathrm{dm}^{-3}$.

\section{DISCUSSION}

When the effect of bioaugmenting the anaerobic digestion process with a specific microorganism is positive, it can result in two effects: an enhancement in methane yield and/or an increase in the methane production rate. If an increase in methane yield is observed, it results from increasing the ultimate bioavailability of the substrate. Increased methane production rate results from faster conversion of the substrate(s) involved in the limiting conversion step. Improved enzymatic hydrolysis should primarily help to reduce the duration of the hydrolytic step. This was the main effect observed in this study. The addition of lipases and lipolytic microorganisms has been successfully used to treat wastewaters containing high levels of lipids under aerobic conditions. ${ }^{2,12,13}$ The enzyme and/or the microorganisms are in many cases added to the aeration step at wastewater treatment plants. Regarding anaerobic digestion, this treatment strategy, when applied, has been done under aerobic conditions before digestion. The results in this case are contradictory. ${ }^{12,13}$ The major drawback of using bioaugmentation under anaerobic conditions is the accumulation of LCFAs, which may inhibit the digestion process. In a previous study on the influence of lipid concentrations on hydrolysis and biomethanation of lipid-rich waste, the addition of a commercial lipase improved lipid hydrolysis. ${ }^{33}$ In the same study, the inhibition of 

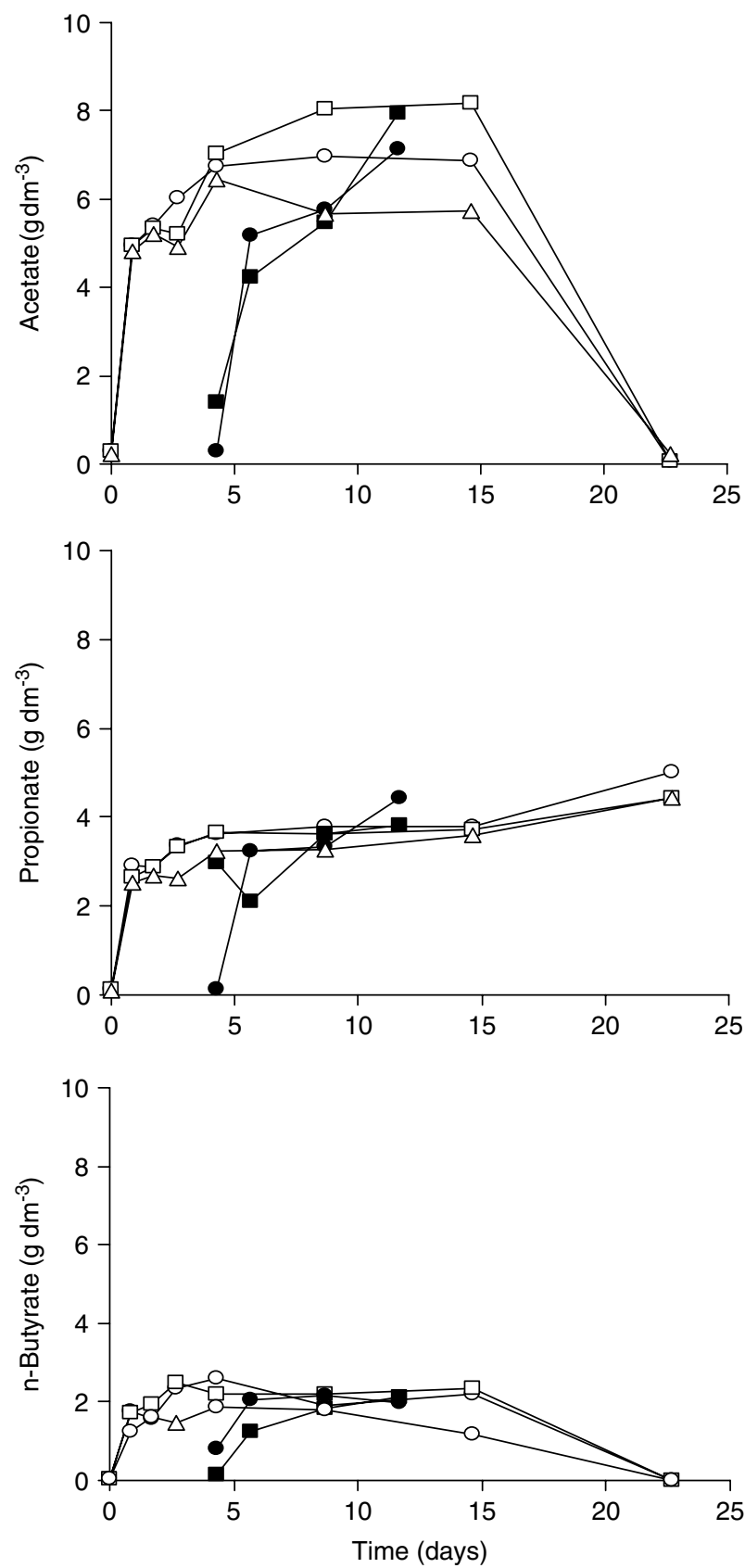

Figure 4. VFA profiles up to day 22 in treatments $A$ and $B$ (after the addition of methanogenic inoculum). Only acids with concentrations above $1.5 \mathrm{~g} \mathrm{dm}^{-3}$ were considered. Filled symbols refer to data for treatment B. -O- control $1 ;-\triangle$ - control $2 ;-\square$ - test sample.

methane production caused by LCFA accumulation was found to be more significant than the inhibition due to VFA accumulation. In view of this, the effect of bioaugmentation of the process with an anaerobic lipolytic microorganism rather than just the enzyme, was seen as an interesting alternative. Bioaugmentation offers the possibility of enzyme production over a longer period of time provided that the microorganism added is able to compete with the other microbes present in the reactor. This could be advantageous for the hydrolysis of lipids once LCFA inhibition effects start to decrease. Another advantage of bioaugmentation is the possibility of improving the conversion of LCFAs.
The results of these experiments show a positive effect for treatment A conditions, i.e. when the lipolytic active bacterium biomass and methanogenic inoculum were added from the start. The probable reason why no positive effect was observed under initially acidogenic conditions can be related to the surface area available for hydrolysis. Sanders ${ }^{1}$ reported that methane had a positive influence on the hydrolysis of lipids because it reduces the coagulation of the lipid spheres, increasing the lipid-water interface.

Considering the results obtained for treatment A conditions: higher methane production rate, higher concentration of palmitate and similar patterns of VFAs in experimental samples and controls, the hypothesis of the bioaugmenting strain improving the oxidation rate of LCFAs appears feasible. The results of a kinetic study of the influence of biomass-associated LCFA concentration on methane production rate conducted by Pereira and coauthors $^{27}$ indicated that for concentrations below approximately $1000 \mathrm{mg}$ COD-LCFA g ${ }^{-1} \mathrm{VS}$, there was no inhibition of methane production rate. This value results from fitting an enzymatic kinetics model considering substrate inhibition. Therefore, at LCFA concentrations below this limit, the methane production rate is expected to increase with increasing biomass-associated LCFA concentration. With the amount of lipid used in this study, the maximum concentration of biomass-associated LCFA possible (170 $\mathrm{mg} \mathrm{COD-LCFA} \mathrm{g}^{-1} \mathrm{VS}$ ) is below this proposed limit, which could explain the higher methane production rate observed. On the other hand, the lipolytic strain utilized in this study, Clostridium lundense, has been isolated recently and its metabolism has not yet been extensively studied. ${ }^{17}$ In the present study, the higher methane production rate could be a consequence of improved $\beta$-oxidation, resulting in a high concentration of palmitate with simultaneous release of hydrogen, which is consumed by hydrogenotrophic methanogens. Another anaerobic lipolytic bacterium, Thermosyntropha lipolytica, was reported to utilize LCFAs by $\beta$-oxidation in syntrophic coculture with a methanogenic archaeum. ${ }^{28}$

For practical reasons, the first sample was taken almost $1 \mathrm{~h}$ after finishing mixing the serum bottles, which could explain the higher initial concentration of biomass-associated oleate observed in the experiment with the active lipolytic strain. The presence of the lipase contributes to a rapid hydrolysis of triolein and increases the surface area available for hydrolysis. Also, the adsorption of LCFAs to biomass is usually a fast process, particularly when a high specific area is available, which could be the case in this study since suspended biomass was used. ${ }^{29}$ After the initial high concentration, the biomass-associated oleate concentration decreased, while stearate and palmitate concentrations increased. The palmitate concentration in the test sample remained higher than in the controls until day 15 . These results are in agreement with those reported recently by other authors ${ }^{7,11}$ (and by 
Cirne and co-workers, unpublished data) who found palmitate to be the most abundant LCFA during the anaerobic digestion of lipid-rich wastes. The presence of higher concentrations of stearate and palmitate throughout the experiment was a clear indication that the bioaugmentation strategy improved the hydrolysis.

The faster degradation of acetate than propionate under methanogenic conditions is in agreement with the findings of Salminen and co-workers. ${ }^{11}$ These authors found that LCFAs caused inhibition of propionate degradation. Pereira and co-workers ${ }^{27}$ also reported a delay in the initial specific methane production when propionate was used as substrate, when using a methanogenic inoculum with associated LCFAs. The slight increase in propionate concentration observed in treatment A cannot be explained by the simultaneous decrease in stearate and palmitate concentrations. These acids have an even number of carbon atoms, and the end products of their degradation via the $\beta$-oxidation pathway are acetate and hydrogen. Therefore, once these acids start to degrade, an increase in acetate concentration would be observed only if aceticlastic methanogenesis was inhibited.

Recent developments in microbial ecology, mainly the development of molecular tools that allow the study of bacteria without isolation and cultivation, offer the possibility of monitoring bacterial species in their ecosystem. ${ }^{30}$ However, this is only possible provided that the microorganism(s) of interest are present in numbers that are detectable with the method employed. ${ }^{31}$ In this study, the fate of the bioaugmenting strain was followed only by monitoring the parameter of interest (lipolytic activity). Cultivation on a selective medium was not suitable because the methanogenic inoculum also contained other lipolytic microorganisms. The problem with the approach adopted in this study was that as hydrolysis occurred rapidly, the lipolytic activity could not be accurately related to the presence of an active lipolytic strain. Additionally, the lipolytic activity was monitored only in the bulk liquid, excluding substrateand cell-bound enzyme. Thus it was not possible to draw conclusions about the survival of the biaugmenting lipolytic strain during the experiment. The possibility of investigating its survival by spiking the serum bottles with triolein and measuring the lipolytic activity, could be an alternative, however, this determination could also be deficient due to possible binding of the lipase produced to the substrate and the biomass.

From a practical point of view, the effect of utilization of bioaugmentation as a strategy to improve the digestion of lipid-containing wastes is a decrease in the time required for digestion. A reduction of $5 \%$ in digestion time was reported for digestion of slaughterhouse wastewater after an enzymatic pretreatment with pancreatic lipase. ${ }^{32}$ In this case, to achieve $80 \%$ of the methane yield the decrease in time of digestion was approximately $30 \%$.

\section{CONCLUSIONS}

In this study the effect of bioaugmentation with an anaerobic lipolytic microorganism on the anaerobic digestion process was evaluated using a model substrate containing triolein as lipid. It was concluded that the addition of the bioaugmenting lipolytic strain led to an increase in the methane production rate and accordingly, a reduction in the digestion period required to obtain the same methane yield as the control. However, it was not possible to draw conclusions about the survival of the bioaugmenting lipolytic strain during the experiments. Overall the LCFAs appeared to limit the complete conversion of the substrate to methane and carbon dioxide. Ways of overcoming the problems related to $\beta$-oxidation must thus be further investigated. Additional studies on the ability of the lipolytic strain, Clostridium lundense, to carry out $\beta$-oxidation in syntrophic coculture with a methanogenic archaeum should be investigated and bioaugmentation with a $\beta$-oxidizer may be an alternative.

\section{ACKNOWLEDGEMENTS}

Fundação para a Ciência e a Tecnologia (FCT), Portugal (grant SFRH/BD/6318/2001) and the Swedish Energy Agency are thanked for supporting this work.

\section{REFERENCES}

1 Sanders WTM, Anaerobic digestion of complex substrates. $\mathrm{PhD}$ thesis, Sub-department of Environmental Technology, Wageningen Agricultural University (2001).

2 Mendes AA, Ferreira HC, Pereira EB and Junior AF, Aplicação de lipases no tratamento de águas residuárias com elevados teores de lipídeos. Quim Nova 28:296-305 (2005).

3 Quéméneur M and Marty Y, Fatty acids and sterols in domestic wastewaters. Water Res 28:1217-1226 (1994).

4 Broughton MJ, Thiele JH, Birch EJ and Cohen A, Anaerobic batch degradation of sheep tallow. Water Res 32:1423-1428 (1998).

5 Hansen KH, Ahring BK and Lutgarde R, Quantification of syntrophic fatty acid- $\beta$-oxidizing bacteria in a mesophilic biogas reactor by oligonucleotide probe hybridization. Appl Environ Microbiol 65:4767-4774 (1999).

6 Masse L, Kennedy KJ and Chou SP, Testing of alkaline and enzymatic hydrolysis pretreatments for fat particles in slaughterhouse wastewater. Bioresource Technol 77:145-155 (2001).

7 Pereira MA, Pires OC, Mota M and Alves MM, Anaerobic degradation of oleic acid by suspended and granular sludge: identification of palmitic acid as key intermediate. Water Sci Technol 45:139-144 (2002).

8 Rollón AP, Anaerobic digestion of fish processing wastewater with special emphasis on hydrolysis of suspended solids. PhD thesis, Sub-department of Environmental Technology, Wageningen Agricultural University (1999).

9 Sayed SKI, van der Zanden J, Wijiffels R and Lettinga G, Anaerobic degradation of the various fractions of slaughterhouse wastewater. Biol Waste 23:117-142 (1988).

10 Petruy $R$ and Lettinga G, Digestion of milk-fat emulsion. Bioresource Technol 61:141-149 (1997).

11 Salminen E, Rintala J, Lokshina LYa and Vavilin VA, Anaerobic batch degradation of solid poultry slaughterhouse waste. Water Sci Technol 41:33-41 (2000). 
12 Masse L, Massé DI, Kennedy KJ and Chou SP, Neutral fat hydrolysis and long-chain fatty acid oxidation during anaerobic digestion of slaughterhouse wastewater. Biotechnol Bioeng 79:43-52 (2002).

13 Cammarota MC, Teixeira GA and Freire DMG, Enzymatic pre-hydrolysis and anaerobic degradation of wastewaters with high fat contents. Biotechnol Lett 23:1591-1595 (2001).

14 Mongkolthanaruk W and Dharmsthiti S, Biodegradation of lipid-rich wastewater by a mixed bacterial consortium. Int Biodeter Biodegr 50:101-105 (2002).

15 Angelidaki I and Ahring BK, Methods for increasing the biogas potential from the recalcitrant organic matter contained in manure. Water Sci Technol 41:189-194 (2000).

16 Mladenovska Z, Ishøy $T$, Mandiralioglu A, Westermann P and Ahring BK, Bioaugmentation of a mesophilic biogas reactor by anaerobic xylanolytic and cellulolytic bacteria, in Proceedings of $9^{\text {th }}$ World Congress on Anaerobic Digestion, Part 1, ed. by Van Velsen AFM and Verstraete WH. Technologisch Instituut vzw, Antwerpen, pp 183-188 (2001).

17 Cirne DG, Delgado O, Marichamy S and Mattiasson B, Clostridium lundense sp. nov., a novel anaerobic lipolytic bacterium isolated from bovine rumen. Int $\mathcal{f}$ Syst Evol Micr 56:625-628 (2006).

18 Jantsch TG, Angelidaki I, Schmidt JE, Braña de Hvidsten BE and Ahring BK, Anaerobic biodegradation of spent sulphite liquor in a UASB reactor. Bioresource Technol 84:15-20 (2002).

19 Markossian S, Becker P, Märkl H and Antranikian G, Isolation and characterization of lipid degrading Bacillus thermoleovorans IHI-91 from an Icelandic hot spring. Extremophiles 4:365-371 (2000).

20 Colleran E, Concannon F, Goldem T, Geoghegan F, Crumlush $\mathrm{B}$, Killilea E, et al, Use of methanogenic activity tests to characterize anaerobic sludges, screen for anaerobic biodegradability and determine toxicity thresholds against individual anaerobic trophic groups and species. Water $\mathrm{Sci}$ Technol 25:31-40 (1992).

21 Mshandete A, Björnsson L, Kivaisi AK, Rubindamayugi ST and Mattiasson B, Enhancement of anaerobic batch digestion of sisal pulp waste by mesophilic aerobic pre-treatment. Water Res 39:1559-1575 (2005)

22 Bligh EG and Dyer WJ, A rapid method of total lipid extraction and purification. Can $\mathcal{F}$ Biochem Physiol 37:911-917 (1959).
23 Christie WW, Gas Chromatography and Lipids, a Practical Guide, 1st edn. The Oily Press, Ayr (1989).

24 Lyberg A-M, Adlercreutz D and Adlercreutz P, Enzymatic and chemical synthesis of phosphatidylcholine regioisomers containing eicosapentaenoic acid or docosahexaenoic acid. Eur F Lipid Sci Technol 107:279-290 (2005).

25 American Public Health Association, American Water Works Association and Water Environmental Federation. Standard Methods for the Examination of Water and Wastewater, 19th edn. APHA, Washington, DC (1995).

26 Winkler UK and Stuckmann M, Glycogen, hyaluronate, and some other polysaccharides greatly enhance the formation of exolipase by Serratia marcescens. F Bacteriol 138:663-670 (1979).

27 Pereira MA, Sousa DZ, Mota M and Alves MM, Mineralization of LCFA associated to anaerobic sludge: kinetics, transport limitations, enhancement of methanogenic activity and effect of VFA. Biotechnol Bioeng 88:502-510 (2004).

28 Svetlitshnyi V, Rainey F and Wiegel J, Thermosyntropha lipolytica gen. nov., sp. nov., a lipolytic, anaerobic, alkalitolerant, themophilic bacterium utilizing short- and long-chain fatty acids in syntrophic coculture with a methanogenic archaeum. Int $\mathcal{F}$ Syst Bacteriol 46:1131-1137 (1996).

29 Hwu C-S, Tseng S-K, Yuan C-Y, Kulik Z and Lettinga G, Biosorption of long-chain fatty acids in UASB treatment process. Water Res 32:1571-1579 (1998).

30 Bouchez T, Patureau D, Dabert P, Juretschko S, Doré J, Delgenès $\mathrm{P}$, et al, Ecological study of a bioaugmentation failure. Environ Microbiol 2:179-190 (2000).

31 Boon N, Goris J, De Vos P, Verstraete W and Top EM, Bioaugmentation of activated sludge by an indigenous 3chloroaniline-degrading Comamonas testosteroni strain, I2gfp. Appl Environ Microbiol 66:2906-2913 (2000).

32 Masse L, Massé DI and Kennedy KJ, Effect of hydrolysis pretreatment on fat degradation during anaerobic digestion of slaughterhouse wastewater. Process Biochem 38:1365-1372 (2003)

33 Cirne DG, Paloumet X, Björnsson L, Alves MM and Mattiasson B, Anaerobic digestion of lipid-rich waste - effects of lipid concentration. Renew Energ (in press). 